\title{
PENGARUH EKSENTRISITAS PUSAT MASSA BANGUNAN BETON BERTULANG TERHADAP STABILITAS STRUKTUR YANG MENGALAMI BEBAN GEMPA
}

\author{
Jati Sunaryati ${ }^{1}$, Ruddy Kurniawan ${ }^{2}$, Eko Sukma Putra ${ }^{3}$
}

\begin{abstract}
ABSTRAK
Untuk mengurangi resiko gempa bumi, perilaku struktur harus diketahui terlebih dahulu. Analisa ini dimaksudkan untuk mengetahui perilaku struktur terhadap gempa bumi bila pada stuktur tersebut mempunya eksentrisitas $e$ terhadap pusat massa dan pusat rotasi. Eksentrisitas ini terjadi karena pusat rotasi dan pusat massa pada gedung tidak berimpit. Dengan adanya hal ini mengakibatkan gedung akan mengalami momen torsi yang mengakibatkan gedung mengalami puntir. Analisa yang digunakan adalah dengan Analisa 3 Dimensi, dimana analisa dengan memperhitungkan beban statis dan dinamis. Analisis ini dimaksudkan untuk melihat pengaruh eksentrisitas bangunan terhadap gaya-gaya yang bekerja pada bangunan. Periode natural struktur, gaya dalam struktur dan lendutan dipengaruhi oleh besarnya eksentrisitas, dimana bangunan model $1(e=22.458)$, model $2(e=18.057)$, model $3(e=13.943)$ dan model $4(e=10.079)$ semakin kecil eksentrisitas, maka semakin kecil periode natural struktur dengan selisih maksimum sebesar $\pm 18 \%$ dan semakin kecil gaya dalam struktur dengan selisih maksimum sebesar $\pm 21 \%$ dan semakin kecil lendutan dengan selisih maksimum sebesar $\pm 15 \%$.
\end{abstract}

Kata Kunci : gempa bumi, perilaku struktur, eksentrisitas.

\section{PENDAHULUAN}

Salah satu faktor yang harus diperhatikan dalam perencanaan bangunan tahan gempa adalah timbulnya momen torsi pada elemen bangunan. Timbulnya momen torsi tersebut disebabkan adanya eksentrisistas antara pusat massa bangunan dengan pusat rotasi bangunan. Pusat massa adalah letak titik tangkap resultante beban mati dan beban hidup yang sesuai yang bekerja pada lantai tingkat tersebut. Sedangkan pusat rotasi (pusat kekakuan) adalah titik dimana pada suatu lantai bangunan, apabila bekerja gaya horizontal pada titik tersebut, lantai tingkat tersebut tidak mengalami rotasi tapi hanya bertranslasi (BSN, 2002).

Letak pusat massa dan pusat rotasi struktur gedung, tidak selalu terletak pada tempat yang sama. Pada gedung perkantoran ini bentuk denah yang dianalisa adalah bentuk " $\mathrm{C}$ " dengan perbedaan luas denah dengan bentuk denah yang tidak beraturan ini tentu saja mengakibatkan letak pusat massa dan pusat rotasi lantai tingkat tidak berimpit, sehingga menimbulkan eksentrisitas.

Dalam tulisan ini akan dianalisis pengaruh eksentrisitas bangunan terhadap gaya-gaya yang bekerja pada bangunan. Adapaun pengaruh eksentrisitas tersebut dapat ditinjau melalui periode natural struktur, gaya-gaya dalam struktur dan lendutan (defleksi) yang terjadi pada struktur.

Adapun stuktur yang ditinjau adalah struktur bangunan beton 7 lantai dengan denah seperti pada Gambar 1, Gambar 2, Gambar 3 dan Gambar 4. Denah bangunan dengan jarak antar kolom 6,0 $\mathrm{m}$ dan tinggi tipikal 4,0 $\mathrm{m}$.

\footnotetext{
${ }^{1}$ Staf Pengajar Jurusan Teknik Sipil Fakultas Teknik Universitas Andalas, e-mail: jati@ft.unand.ac.id

${ }^{2}$ Staf Pengajar Jurusan Teknik Sipil Fakultas Teknik Universitas Andalas, e-mail: ruddykurniawan@ft.unand.ac.id

${ }^{3}$ Mahasiswa Jurusan Teknik Sipil Fakultas Teknik Universitas Andalas
} 


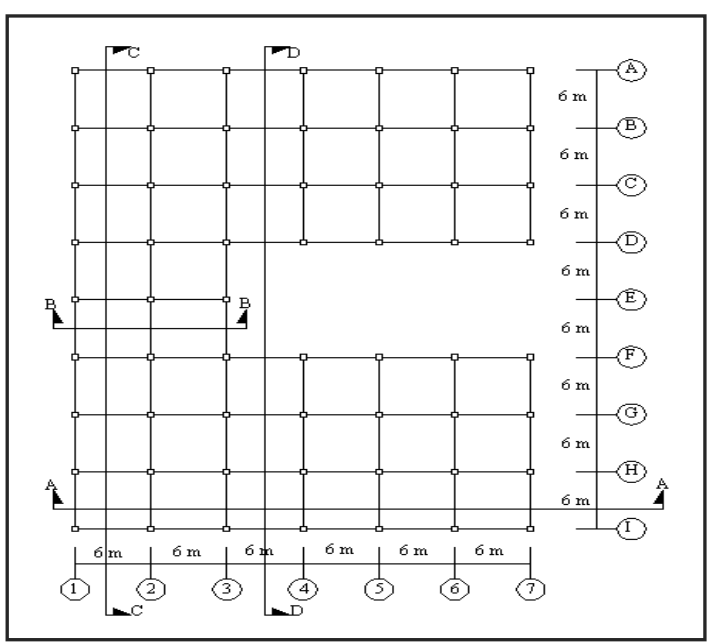

Gambar 1. Denah Model 1

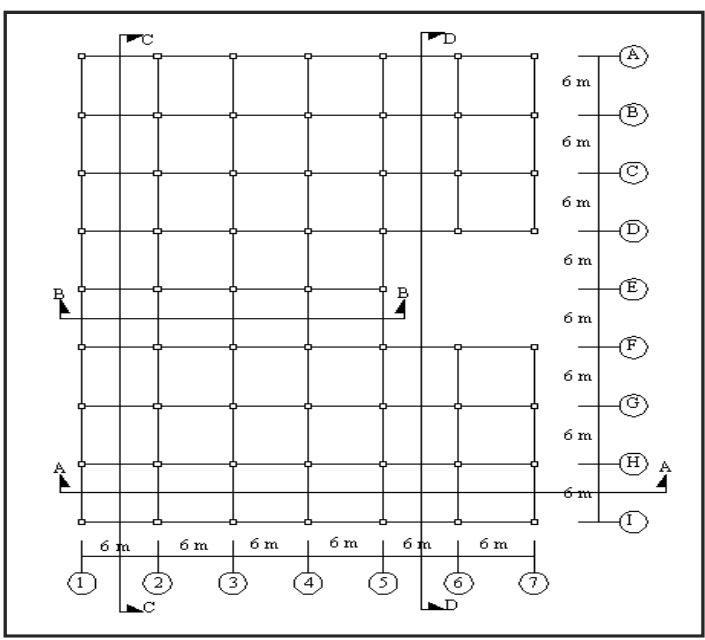

Gambar 3. Denah Model 3

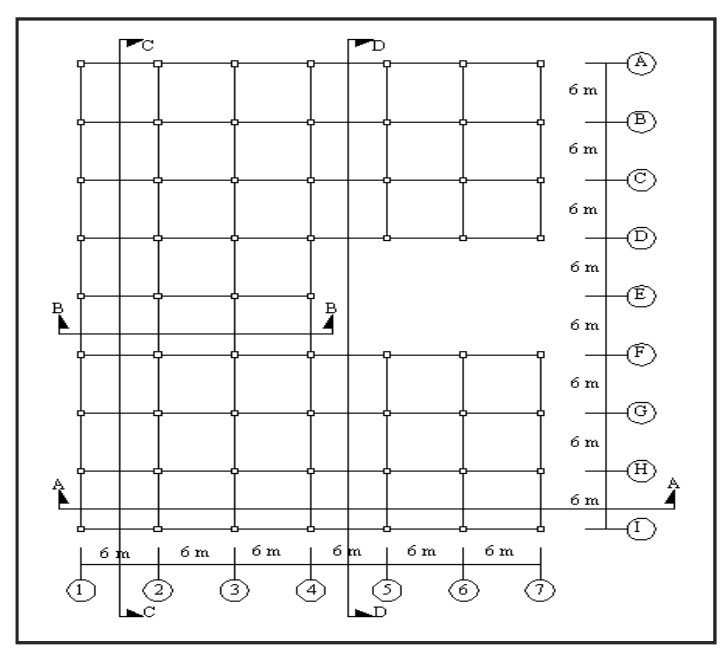

Gambar 2. Denah Model 2

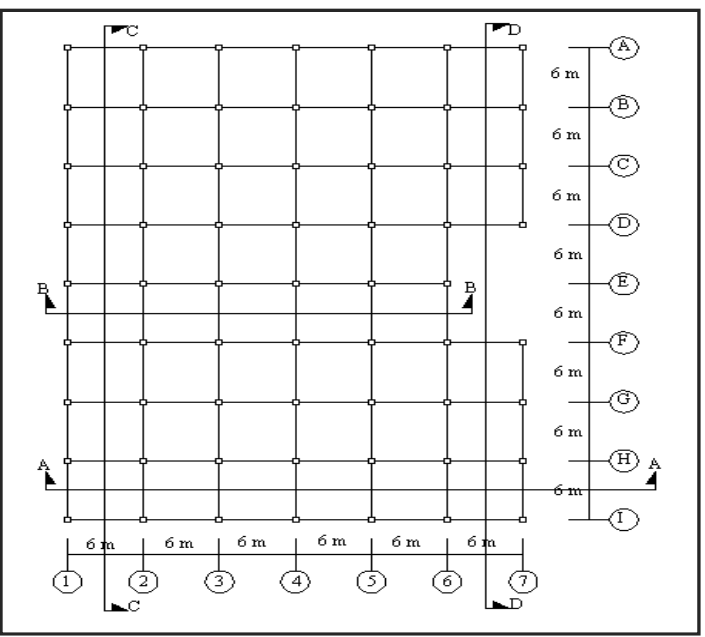

Gambar 4. Denah Model 4

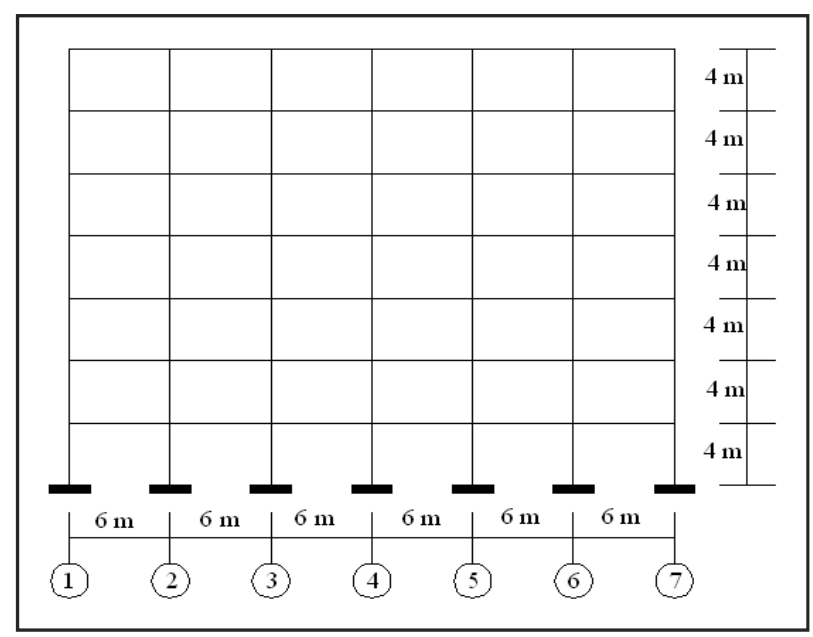

Gambar 5. Potongan A (Denah Model 1, Model 2, Model 3, Model 4) 


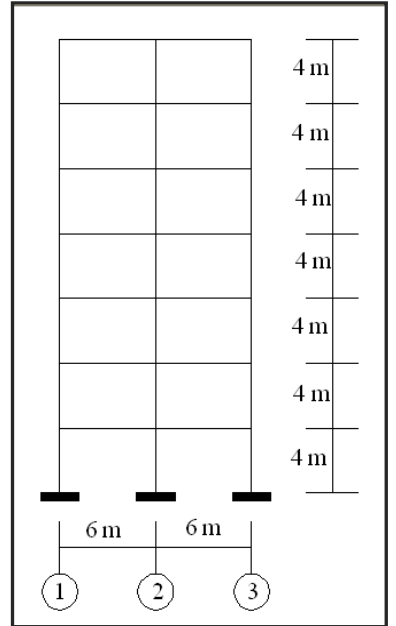

Gambar 6. Potongan B (Denah Model 1)

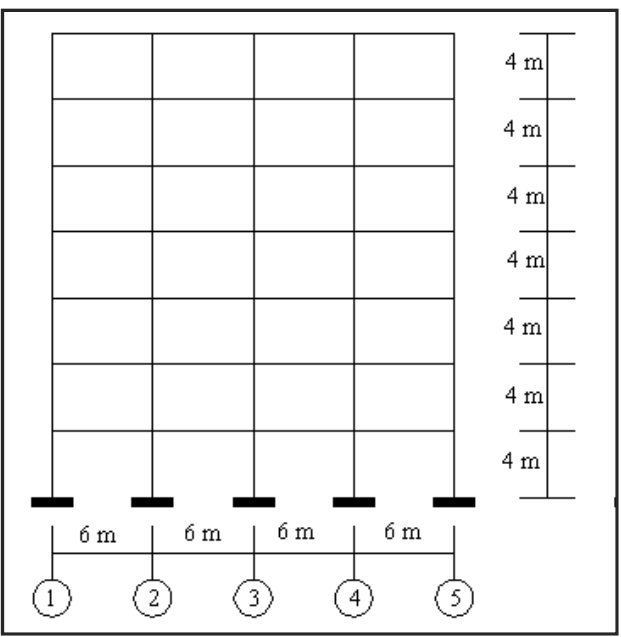

Gambar 8. Potongan B (Denah Model 3)

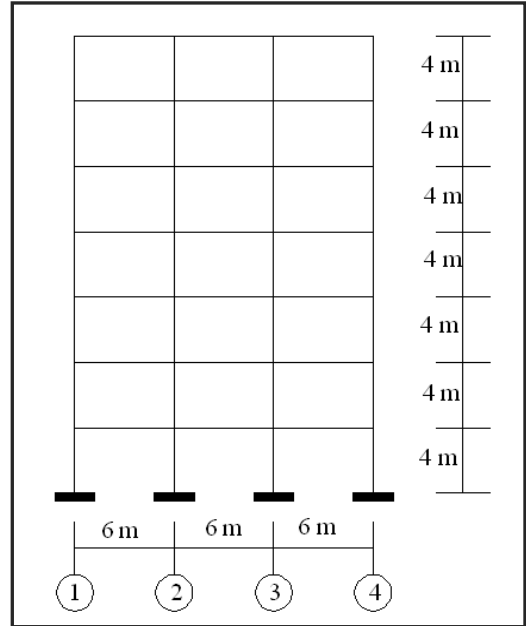

Gambar 7. Potongan B (Denah Model 2)

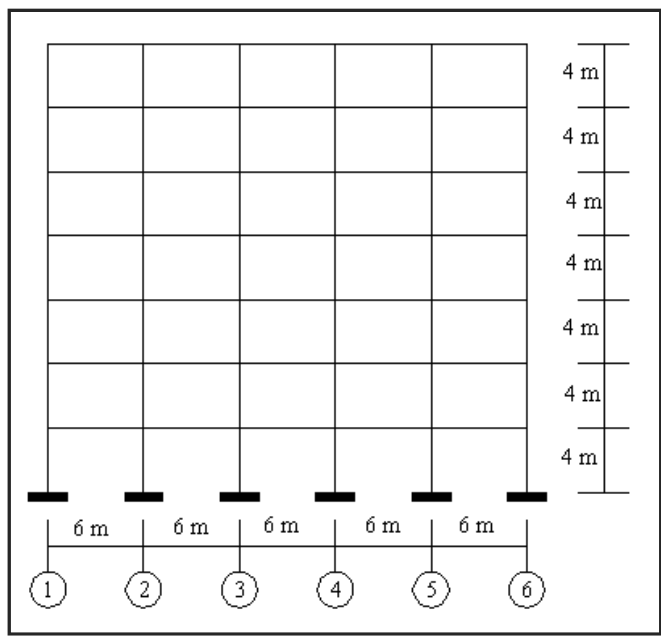

Gambar 9. Potongan B (Denah Model 4)

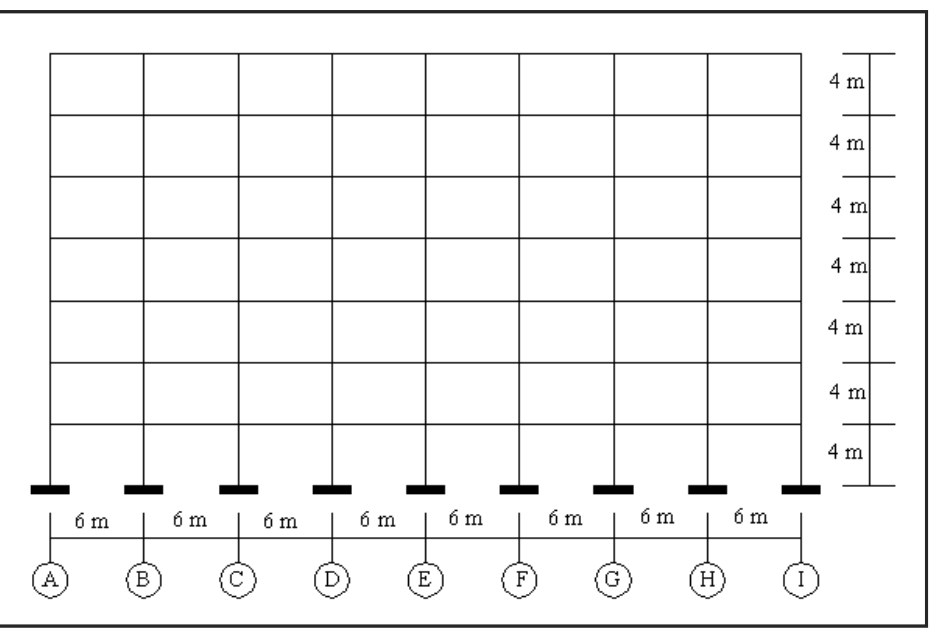

Gambar 10. Potongan C (Denah Model 1, Model 2, Model 3, Model 4) 


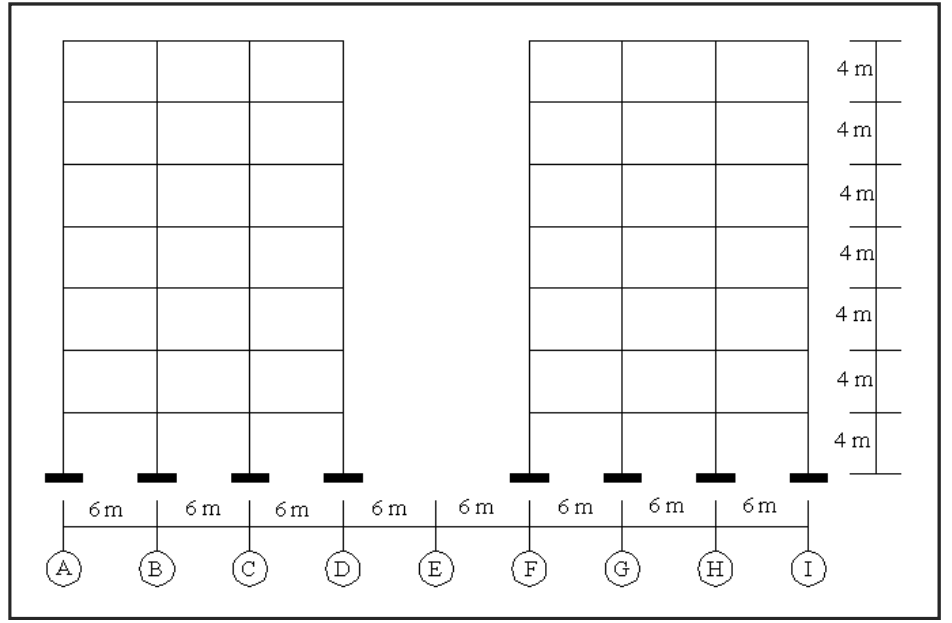

Gambar 11. Potongan D (Denah Model 1, Model 2, Model 3, Model 4)

\section{EKSENTRISITAS PADA STRUKTUR}

Eksentrisitas terjadi karena pusat rotasi dan pusat massa pada gedung tidak berimpit, dengan adanya hal ini mengakibatkan gedung akan mengalami momen torsi yang mengakibatkan gedung mengalami punter, contohnya pada struktur yang tidak beraturan.

Pusat massa adalah letak titik tangkap resultan beban mati dan beban hidup yang sesuai yang bekerja pada lantai tingkat tersebut. Sedangkan pusat rotasi (pusat kekakuan) adalah titik dimana pada suatu lantai bangunan, apabila bekerja gaya horizontal pada titik tersebut, lantai tingkat tersebut tidak mengalami rotasi tapi hanya bertranslasi. Untuk menghitung besarnya eksentrisitas pada bangunan, persamaan yang digunakan tidak selalu sama tergantung pada bentuk denah bangunan itu sendiri atau perbedaan akibat beban mati maupun beban hidup pada lantai yang sama. Untuk menghitung besarnya eksentrisitas yang terjadi pada bangunan dapat dilihat pada persamaan 1, 2, dan 3 untuk bentuk denah seperti pada Gambar 12.
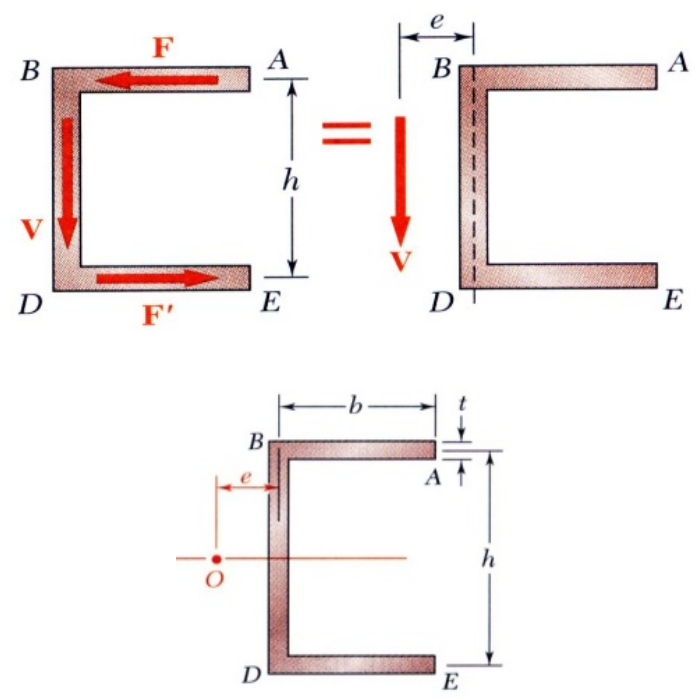

Gambar 12. Eksentrisitas pada Denah Struktur berbentuk "C" 
Dari Gambar 12, didapatkan persamaan sebagai berikut :

$$
\begin{aligned}
F & =\int_{0}^{b} q d s=\int_{0}^{b}\left(\frac{V Q}{I}\right) d s=\frac{V Q}{I} \int_{0}^{b}\left(s t \frac{h}{2}\right) d s=\frac{V t h b^{2}}{4 I} \\
I & =\frac{1}{12} t h^{3}+2\left[\frac{1}{12} b t^{3}+b t\left(\frac{h}{2}\right)^{2}\right] \\
e & =\frac{F h}{V}
\end{aligned}
$$

Dengan :

$$
\begin{array}{ll}
e & =\text { eksentrisitas } \\
F & =\text { gaya geser } \\
I & =\text { momen inersia } \\
h & =\text { jarak } \\
V & =\text { besarnya gaya yang menyebabkan bangunan mengalami puntIr }
\end{array}
$$

\section{STUDI KASUS}

Studi kasus akan dilakukan terhadap empat jenis bentuk geometris denah bangunan yang berbeda, dengan denah seperti pada Gambar 1, Gambar 2, Gambar 3 dan Gambar 4 dengan deskripsi sebagai berikut : jumlah lantai 7, tinggi tiap lantai $4 \mathrm{~m}$, tinggi total gedung $28 \mathrm{~m}$, panjang gedung $36 \mathrm{~m}$, lebar gedung $48 \mathrm{~m}$, mutu bahan $f_{c}^{\prime}=25 \mathrm{MPa}, f_{y}=400 \mathrm{MPa}$, kategori gedung perkantoran, jenis tanah pada lokasi tanah lunak, wilayah gempa 5 (SNI 03-1726-2002).

\section{HASIL}

\subsection{Distribusi Gaya Gempa}
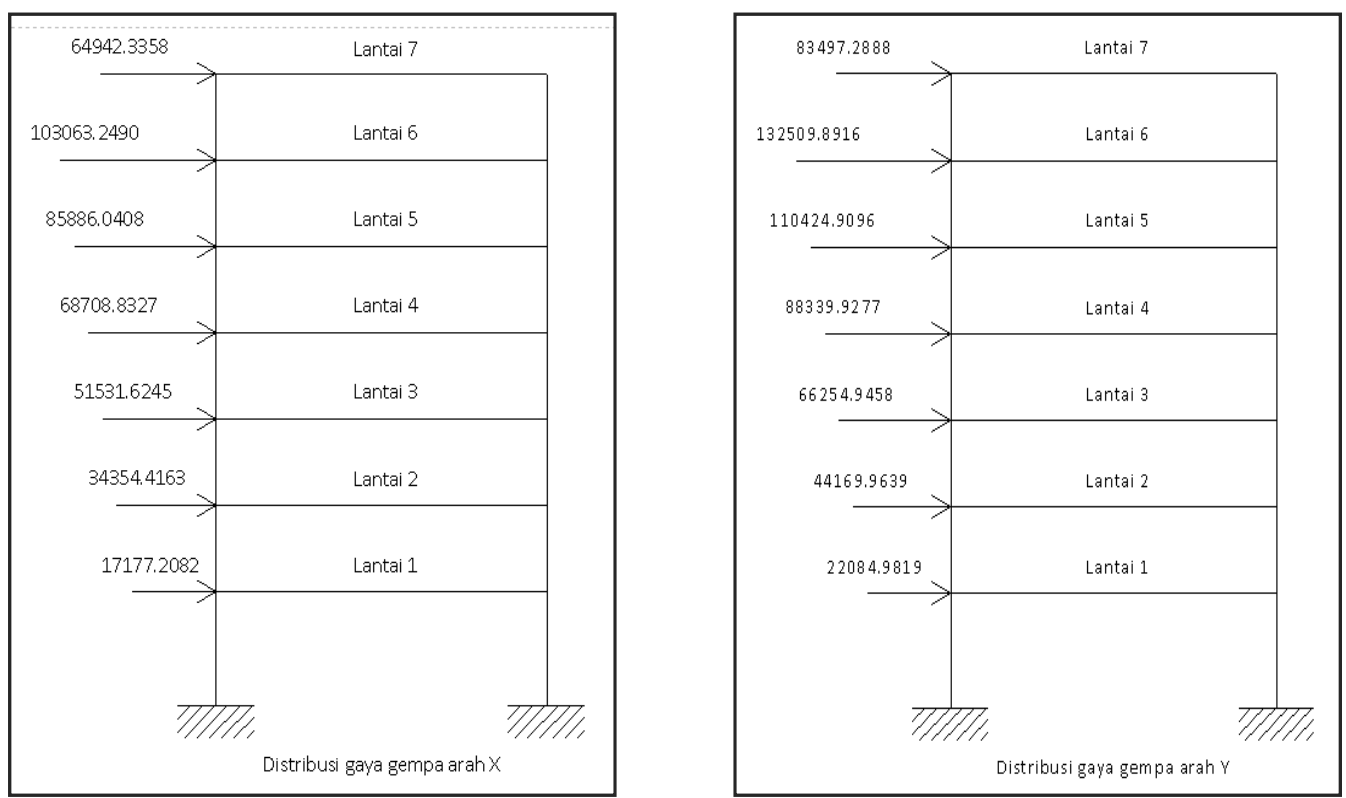

Gambar 13. Distribusi Gaya Gempa Arah - $x$ dan Arah - $y$ untuk Model 1 

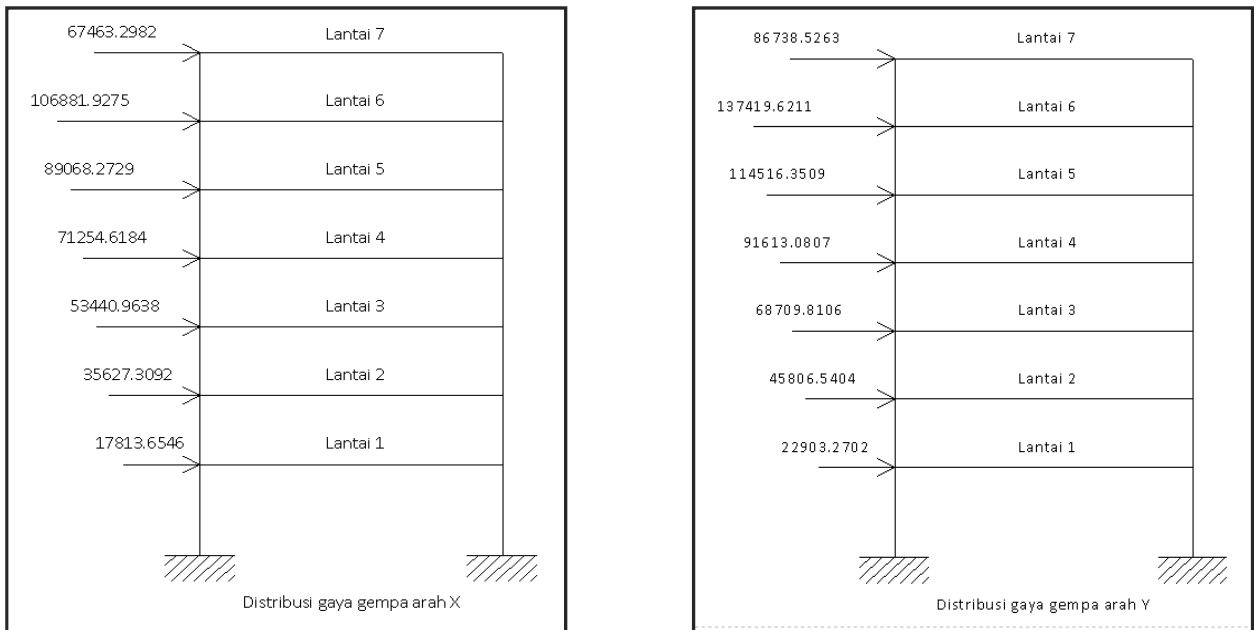

Gambar 14 Distribusi Gaya Gempa Arah - $x$ dan Arah - $y$ untuk Model 2
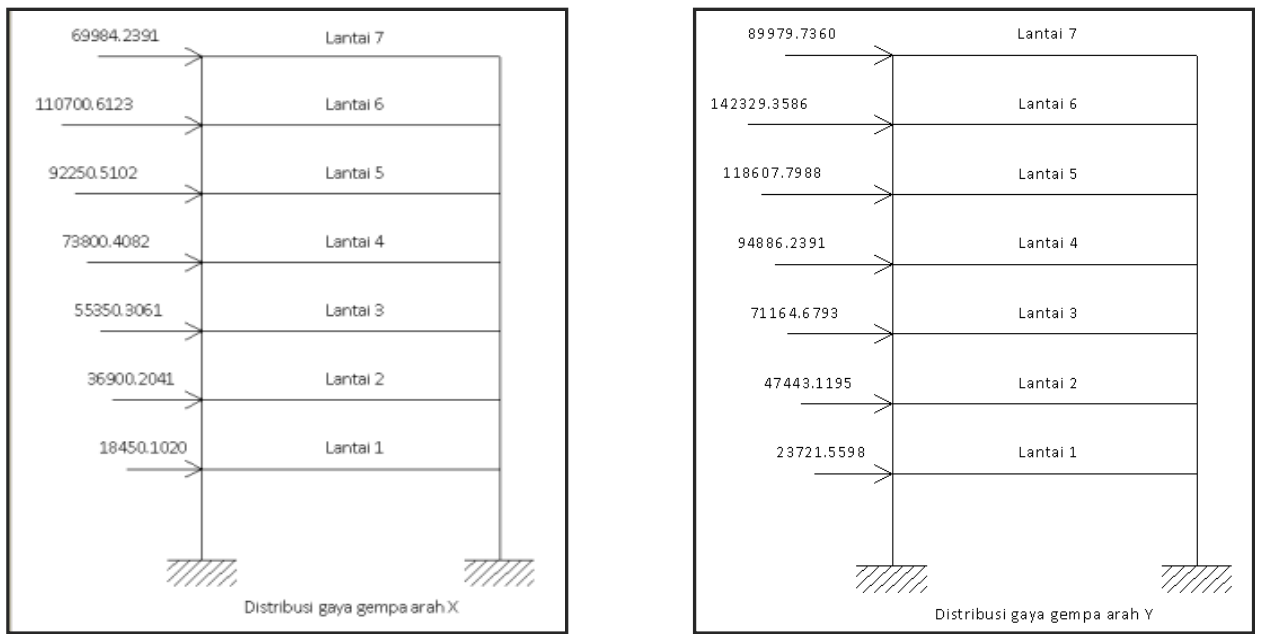

Gambar 15. Distribusi Gaya Gempa Arah - $x$ dan Arah - $y$ untuk Model 3
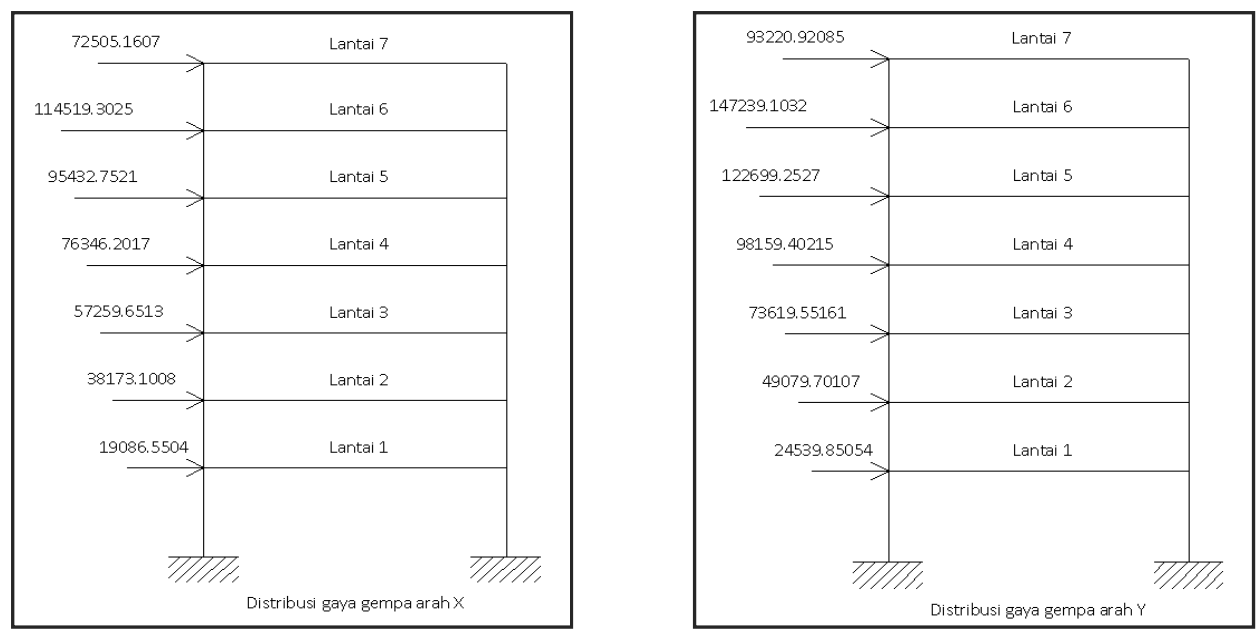

Gambar 16. Distribusi Gaya Gempa Arah - $x$ dan Arah $-y$ untuk Model 4 


\subsection{Periode Natural}

Grafik periode natural bangunan (Gambar 17) diambil sebagai akibat pembebanan respon spektra arah $x$ dan arah $y$, diambil 7 mode, karena jumlah lantai bagunan adalah 7 lantai.

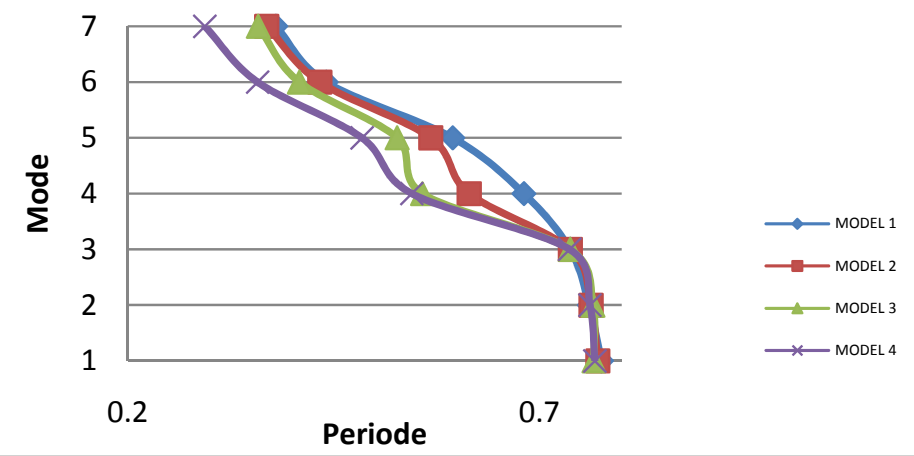

Gambar 17. Periode Natural yang Dialami Struktur Portal Terbuka

\subsection{Gaya Dalam Struktur}

Grafik-grafik (gambar) di bawah ini diharapkan dapat memperlihatkan bagaimana perbedaan nilai eksentrisitas bangunan dalam mempengaruhi gaya-gaya dalam yang bekerja pada kolom utama dan balok utama. Gaya dalam pada kolom dan balok utama ini diambil dari nilai maksimum keseluruhan kombinasi pembebanan.

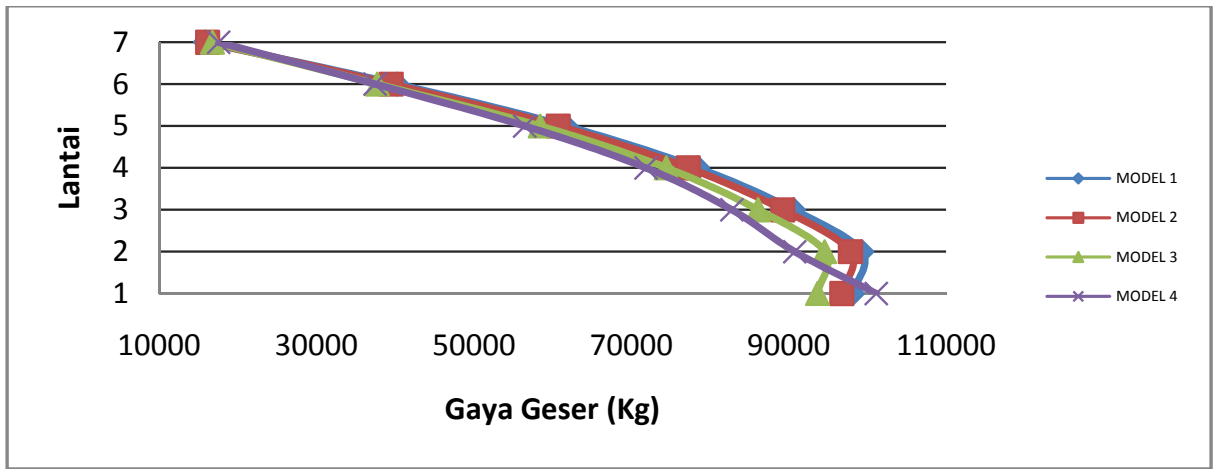

Gambar 18. Gaya Geser yang Dialami Kolom Utama pada Sistem Struktur Portal Terbuka

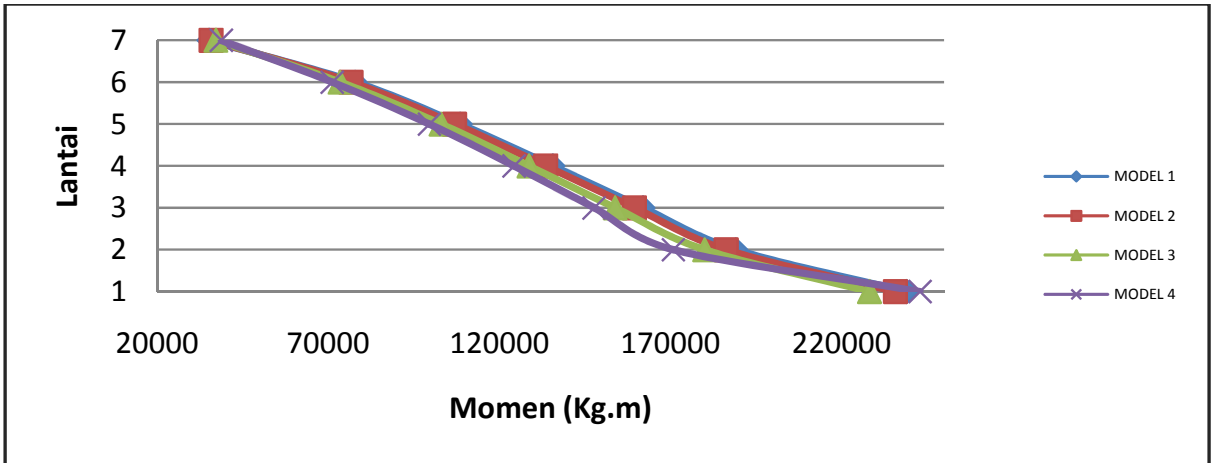

Gambar 19. Momen yang Dialami Kolom Utama pada Sistem Struktur Portal Terbuka 


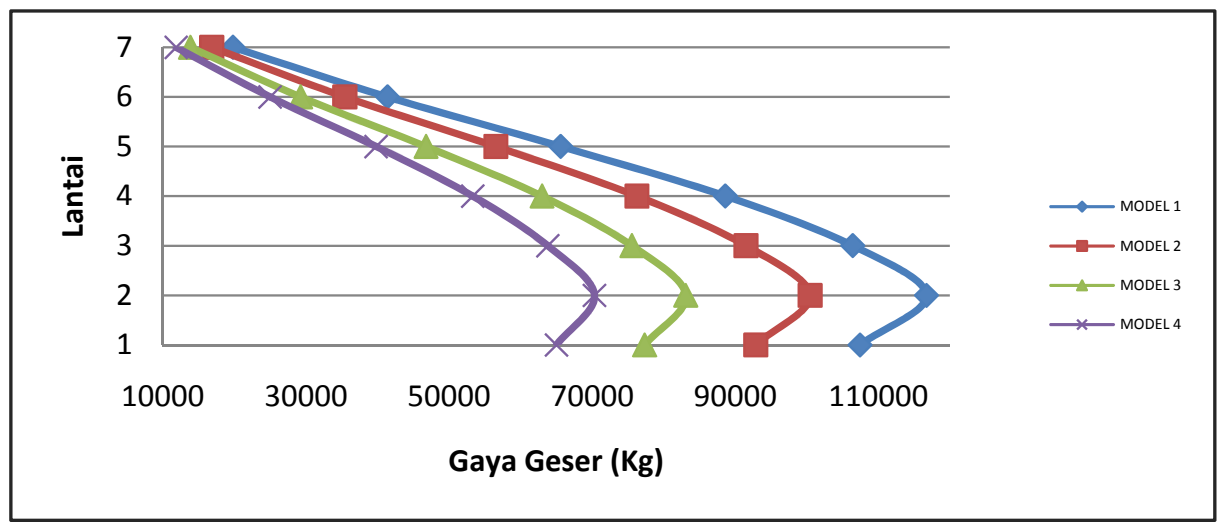

Gambar 20. Gaya Geser yang Dialami Balok Utama pada Sistem Struktur Portal Terbuka

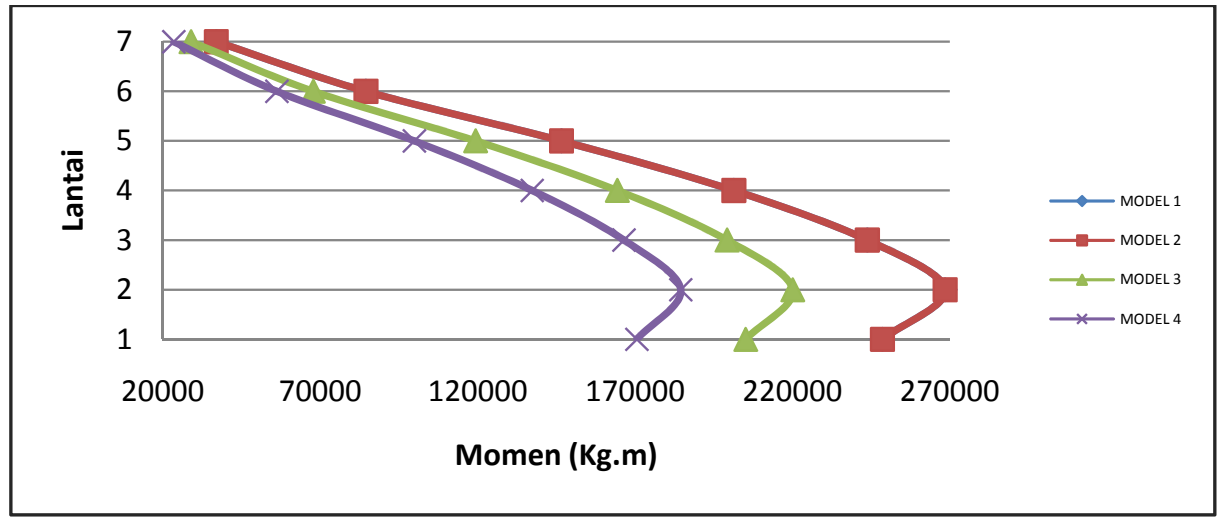

Gambar 21. Momen yang Dialami Balok Utama pada Sistem Struktur Portal Terbuka

\subsection{Lendutan}

Grafik lendutan (defleksi) bangunan (Gambar 22 dan Gambar 23) diambil sebagai akibat kombinasi pembebanan yang diharapkan dapat memperlihatkan kemampuan suatu bangunan dalam menahan lendutan (defleksi).

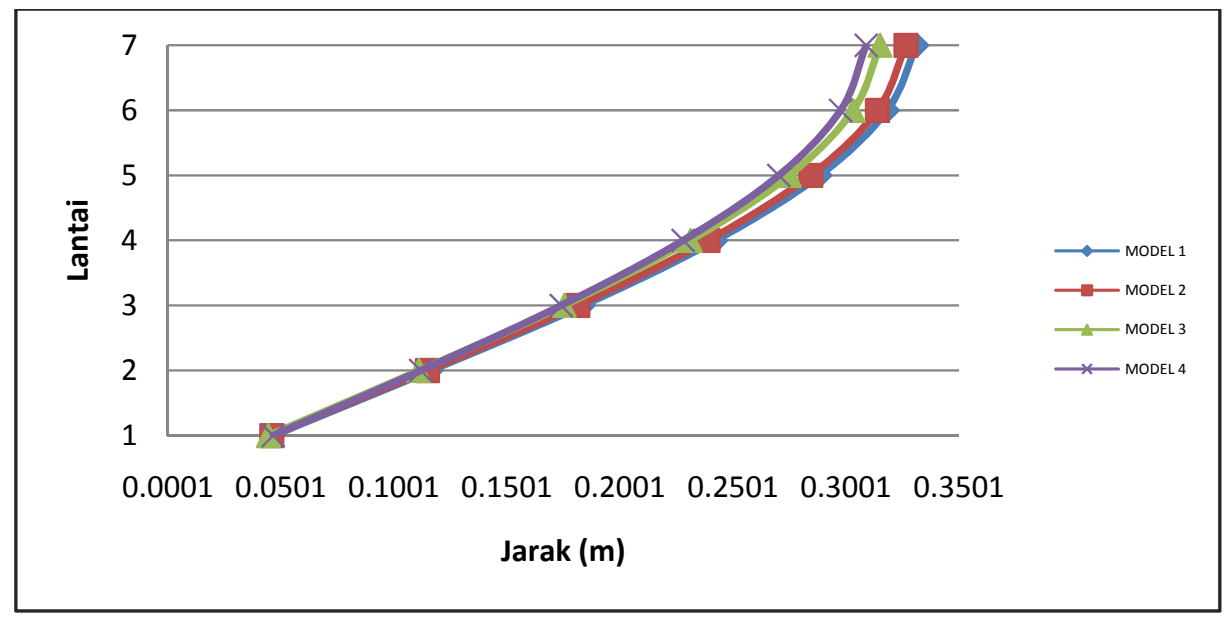

Gambar 22. Lendutan Arah $x$ pada Sistem Struktur Portal Terbuka 


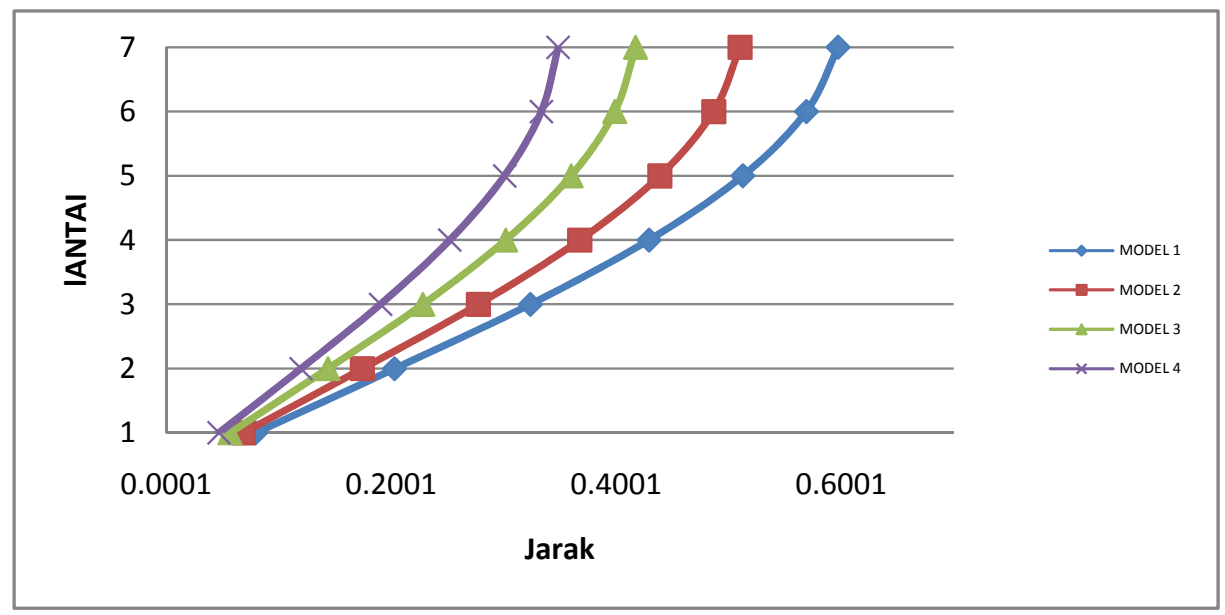

Gambar 23. Lendutan arah y pada Sistem Struktur Portal Terbuka

\section{ANALISA DAN PEMBAHASAN}

\subsection{Periode Natural Struktur}

Pada Gambar 17 dapat dilihat bahwa eksentrisitas berpengaruh terhadap besarnya periode natural struktur, dimana selisih maksimum untuk model 1 dengan eksentrisitas 22.458 dengan model 2 dengan eksentrisitas 18.057 adalah sebesar $\pm 9 \%$, selisih maksimum untuk model 2 dengan eksentrisitas 18.057 dengan model 3 dengan eksentrisitas 13.943 adalah sebesar $\pm 9 \%$, selisih maksimum untuk model 3 dengan eksentrisitas 13.943 dengan model 4 dengan eksentrisitas 10.079 adalah sebesar $\pm 18 \%$. Artinya semakin kecil eksentrisitas juga akan dipengaruhi dengan mengecilnya besar periode natural struktur.

\subsection{Gaya Dalam Struktur}

Pada Gambar 18, Gambar 19, Gambar 21 dan Gambar 22, dapat dilihat bahwa eksentrisitas berpengaruh terhadap gaya dalam struktur dimana selisih maksimum untuk geser dan momen yang dialami kolom pada model 1 dengan eksentrisitas 22.458 dengan model 2 dengan eksentrisitas 18.057 adalah sebesar $\pm 1 \%$, selisih maksimum untuk model 2 dengan eksentrisitas 18.057 dengan model 3 dengan eksentrisitas 13.943 adalah sebesar $\pm 4 \%$, selisih maksimum untuk model 3 dengan eksentrisitas 13.943 dengan model 4 dengan eksentrisitas 10.079 adalah sebesar $\pm 4 \%$. Selisih maksimum untuk geser dan momen yang dialami balok pada model 1 dengan eksentrisitas 22.458 dengan model 2 dengan eksentrisitas 18.057 adalah sebesar $\pm 17 \%$, selisih maksimum untuk model 2 dengan eksentrisitas 18.057 dengan model 3 dengan eksentrisitas 13.943 adalah sebesar $\pm 21 \%$, selisih maksimum untuk model 3 dengan eksentrisitas 13.943 dengan model 4 dengan eksentrisitas 10.079 adalah sebesar $\pm 19 \%$. Artinya semakin kecil eksentrisitas juga akan dipengaruhi dengan mengecilnya besar gaya-gaya dalam struktur.

\subsection{Lendutan (Defleksi) yang Terjadi pada Struktur}

\subsubsection{Lendutan Arah $-X$}

Pada Gambar 22, dapat dilihat bahwa lendutan arah $x$ pada bangunan model 1 ( $e=22.458)$, model $2(e=18.057)$, model $3(e=13.943)$, dan model $4(e=10.079)$ terjadi perbedaan lendutan pada lantai 7 sebesar $\pm 3 \%$, dimana semakin kecil eksentrisitas maka lendutan (defleksi) juga akan semakin kecil. 


\subsubsection{Lendutan Arah $-Y$}

Pada Gambar 23, dapat dilihat bahwa lendutan arah $\underline{x}$ pada bangunan model 1 ( $e=22.458)$, model $2(e=18.057)$, model $3(e=13.943)$, dan model $4(e=10.079)$ terjadi perbedaan lendutan pada lantai 7 , yaitu sebesar sebesar $\pm 15 \%$, dimana semakin kecil eksentrisitas maka lendutan akan semakin kecil.

\section{PENUTUP}

\subsection{Kesimpulan}

Pengaruh yang diberikan oleh perbedaan eksentrisitas bangunan yang masing-masing memiliki keunggulan dan kelemahan sendiri. Namun dari hasil analisa terhadap bangunan pada studi kasus yang diambil dapat ditarik kesimpulan, diantaranya:

- Periode natural struktur dipengaruhi oleh besarnya eksentrisitas, dimana pada bangunan model $1(e=22.458)$, model $2(e=18.057)$, model $3(e=13.943)$, dan model $4(e=10.079)$ semakin kecil eksentrisitas maka semakin kecil periode natural struktur.

- Gaya dalam struktur dipengaruhi oleh besarnya eksentrisitas pada bangunan model $1(e=$ $22.458)$, model $2(e=18.057)$, model $3(e=13.943)$, dan model 4 ( $e=10.079)$ semakin kecil eksentrisitas maka semakin kecil gaya-gaya dalam yang terjadi.

- Lendutan dipengaruhi oleh besarnya eksentrisitas, dimana pada bangunan model 1 ( $e=$ $22.458)$, model $2(e=18.057)$, model $3(e=13.943)$, dan model $4(e=10.079)$ semakin kecil eksentrisitas maka semakin kecil lendutan yang terjadi.

- Denah model 4 merupakan denah paling baik diantara ketiga model lainnya dengan periode natural struktur yang kecil, gaya dalam struktur yang kecil, dan lendutan yang kecil.

\subsection{Saran}

Perlu dilakukan kajian tambahan mengenai perbedaan hasil yang diperoleh antara analisis struktur secara 3 dimensi dengan 2 dimensi pada struktur gedung yang mengalami beban gempa. Pemilihan model hendaknya dilakukan pada struktur yang telah ada dengan nilai eksentrisitas yang besar dan kemudian dicari perbedaan dari hasil yang telah diperoleh.

\section{DAFTAR PUSTAKA}

Beer, P., Ferdinand, (2006), Mechanics of Materials, Higher Education, Singapore.

Paulay, T., and Pristley, M.J.N., (1992), Seismic Design of Reinforced Concrete and Masonry Buildings. John Wiley \& Sons, Inc., Canada.

Purwono, R., dkk., (2005), Perencanaan Struktur Beton Bertulang Tahan Gempa. ITS Press, Institut Teknologi Sepuluh Nopember, Surabaya.

SNI 03-1726-2002, Standar Perencanaan Ketahanan Gempa untuk Struktur Bangunan Gedung, Badan Standarisasi Nasional, Bandung.

SNI 03-2847-2002, Tata Cara Perhitungan Struktur Beton untuk Bangunan Gedung, Badan Standardisasi Nasional, Bandung.

Solikin, Mochamad, Pengaruh Eksentrisitas Pusat Massa Portal Beton Bertulang Terhadap Stabilitas Struktur yang Mengalami Beban Gempa, Universitas Muhammadiyah, Surakarta.

Tavio dan Kusuma, Beny, Desain Sistem Rangka Pemikul Momen dan Dinding Struktur Beton Bertulang Tahan Gempa, ITS Press, Institut Teknologi Sepuluh Nopember, Surabaya. 